\title{
EFFECT OF DRYING CONDITIONS ON THE MICRONUTRIENT CONTENT OF FIVE LEAFY VEGETABLES OF EASTERN NIGERIA
}

\author{
N. NWACHUKWU AND J. U. NWORIE
}

(Received 4, March 2008; Revision Accepted 29, August 2008)

\begin{abstract}
The effect of sun and oven drying at $100^{\circ} \mathrm{C}$ on the micronutrient composition of five selected 'lesser known' leafy vegetables of Eastern Nigeria was investigated. The vegetables are Ipomea batatas (potato leaf), Pterocarpus santolinoides (uturukpa leaf), Zanthoxylium zanthoxyloides (nka leaf), Pterocarpus mildbreadii (oha leaf), and Ceiba pentandra (akpuota leaf). They were divided into three groups, representing fresh (wet), sun dried, and oven dried at $100^{\circ} \mathrm{C}$ until constant weight was obtained before grinding into flour like sample and used for analysis. The minerals analyzed include sodium, potassium, magnesium, manganese, iron, zinc, calcium and phosphorus, while the vitamins include $A, C, E, B_{1}, B_{2}$, and folic acid. The result of fresh analysis shows that $P$. mildbreadii has the highest value; 9.00 $\pm 0.2 \mathrm{mg} / 100 \mathrm{~g}$ of potassium; $Z$.zanthoxzyloides, $1.72 \pm 0.18 \mathrm{mg} / 100 \mathrm{~g}$ of magnesium, $P$. mildbreadii, $6.87 \pm$ $0.18 \mathrm{mg} / 100 \mathrm{~g}$ of iron; Z. zanthoxyloides, $6.47 \pm 0.10 \mathrm{mg} / 100 \mathrm{~g}$ of phosphorus; I.batatas, $14.27 \pm 0.41 \mathrm{mg} / 100 \mathrm{~g}$ of calcium, and $83.79 t 1.41 \mathrm{mg} / 100 \mathrm{~g}$ of sodium respectively. Zinc and manganese occurred in trace amounts. The levels of these elements were generally increased both by sun, and oven drying at $100^{\circ} \mathrm{C}$ with a greater increase when oven dried. Also the result of fresh analysis shows that the highest values of vitamins $A, 15.20 .01 \pm 2.0 \mathrm{i}$.u occurred in I. batatas, vit. $B_{1}, 4.57 \pm 0.86 \mathrm{mg} / 100 \mathrm{~g}$; folic acid, $3.24 \pm 0.00 \mathrm{mg} / 100 \mathrm{~g}$ occurred in $P$. santolinoides respectively, vitamin $C$, $9.04 \pm 0.72 \mathrm{mg} / 100 \mathrm{~g}$ occurred in Z. zanthoxyloides. Vitamins $B_{2}$ and $E$ levels were relatively low. Both sun and oven drying at $100^{\circ} \mathrm{C}$ decreased the levels of all the vitamins, with sun drying exerting a greater reduction effects. Oven drying therefore appears to be a better drying condition.
\end{abstract}

KEYWORDS: Sun drying; oven drying 'lesser known leaf vegetables' Micro-nutrient composition.

\section{INTRODUCTION}

Vegetables constitute an essential component of human diet in Africa and in Nigeria in particular. They are consumed as cooked components to the major staple foods like yam, cassava, maize, etc. Often, they are consumed raw depending on the type (Oguntona, 1998). The varieties of vegetables utilized are as diverse as the staple foods. In fact, it is estimated that green leafy vegetables have over sixty species in Nigeria alone (Okoli et al, 1998).

Due to the wide variation in weather condition in the country, the level and scope of production of the different vegetables differ naturally. It is also known that many communities in Nigeria utilize the leaves of many shrubs and trees, and this constitutes the group of vegetables known as "lesser known" (Oguntona, 1998). The vegetables selected in this study, belong mainly to the "lesser known" group, and are utilized by the lowincome earners within Eastern Nigeria.

Maud, (1999) has noted that in trying to dry vegetables so that storage would be enhanced, most of the food nutrients are lost to the sun.

However, Arthey and Dennis (1991) stated that the extent of vitamin destruction is dependent on the caution exercised during the preparation of the foodstuff for drying, the drying process selected, the care and execution, and the condition of the storage. In fact, they stated that vitamin concentration increases in dried food per a unit weight. Similarly, Nwachukwu, (2002) reported that drying has no effect on some spices, whereas in some it increased the vitamin level.

In this study, we investigated the effect of drying conditions (sun, and oven drying) on the micronutrient content of selected "Lesser known" leafy vegetables of Eastern Nigeria. A good preservation method will make the vegetables available most times of the year. This study will identify or determine which drying method, sun or oven has a better preservative effect on the micronutrient content of the selected vegetables.

\section{MATERIALS AND METHODS}

Materials: The vegetables, Ipomea batatas (potato leaf,), Pterocarpus santollnoides (uturukpa leaf); Xanthoxylium xanthoxyliodes (Nka leaf); Pterocarpus mildbread if (Oha leaf), and Ceiba pentandra (Akpuota leaf) were all collected from farmland at Abakaliki in Ebonyi state. The vegetables were duly certified by a taxonomist;

Processing of samples: The samples were sorted to selected good ones, which was then divided into three portions each for fresh/wet, sun and oven drying at $100^{\circ} \mathrm{C}$ respectively. All the dried samples $(100 \mathrm{~g}$ each) were measured repeatedly until constant weight was 
obtained before grinding into powdered form using milling machine. The flour-like form was sieved with $1 \mathrm{~mm}$ sieve, and then used for all the analysis.

Determination of minerals: Ashing was done according to the method of Odo and Ishiwu (1999).

Determination of vitamins: The method of David, (1978) and Pearson (1978) were used to determine the vitamins.

\section{RESULT}

In table 3.1, the result of mineral content of fresh samples shows that the highest level of potassium, $9.00 \pm 0.27 \mathrm{mg} / 100 \mathrm{~g}$ occurred in P. mlldbreadii, while I. batatas had the least value, $4.50 \pm 0.07 \mathrm{mg} / 100 \mathrm{~g}$. The highest level of magnesium, $1.72 \pm 0.18 \mathrm{mg} / 100 \mathrm{~g}$ occurred in Z. xanthoxyloides, while the least value, $1.31 \pm 0.28 \mathrm{mg} / 100 \mathrm{~g}$ occurred in $P$. mildbreadii. The level of zinc was relatively low, in fact less than $1 \mathrm{mg} / 100 \mathrm{~g}$ in all the samples.

Similarly, manganese levels were the last of the minerals determined in all the samples occurring at less than $1 \mu \mathrm{g} / 100 \mathrm{~g}$. The levels of iron, phosphorus, calcium, and sodium were relatively high in all the samples with the highest levels of iron; $4.39 \pm 0.52 \mathrm{mg} / 100 \mathrm{~g}$; phosphorus; $\quad 8.85 \pm 0.99 \mathrm{mg} / 100 \mathrm{~g}$; calcium $18.88 \pm 0.05 \mathrm{mg} / 100 \mathrm{~g}$, and sodium, $102.00 \pm 0$ $64 \mathrm{mg} / 100 \mathrm{~g}$ occurring in Z. zanthoxyloides; C. pentandra and $\mathrm{L}$. batatas respectively.

Tables 3.2 and 3.3 present the result of mineral content when sun, and oven dried at $100^{\circ} \mathrm{C}$. The levels of potassium, magnesium phosphorus, calcium and sodium were increased by both sun and oven drying at $100^{\circ} \mathrm{C}$ when compared with the result of fresh analysis. However, the levels of zinc, iron and manganese decreased when sun and oven dried at $100^{\circ} \mathrm{C}$ as compared to the result of fresh analysis.

In tables 3.4, the result shows that the content of vitamins $A, B_{1}, C$, and folic acid were relatively high in all

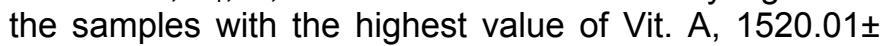
$2.10 \mathrm{mg} / 100 \mathrm{~g}$ i.u, Vit $B_{1} .4 .57 \pm 0.86 \mathrm{mg} / 100 \mathrm{~g}$, Vit. C; 9.04 $\pm 2.10 \mathrm{i}$.u, and folic acid; $3.24 \pm 0.03 \mathrm{mg} / 100 \mathrm{~g}$ occurring in 'I. batatas; P. santolinoides; Z. zanthoxyloides, and P. santolinoides respectively.

Similarly, vitamins $B_{2}$ and $E$ levels were the least in all the samples with the highest levels; $1.59 \pm 0.09 \mathrm{mg} / 100 \mathrm{~g}$ and $1.95 \pm 0.1 \mathrm{mg} / 100 \mathrm{~g}$ in $\mathrm{I}$. batatas respectively.

In table 3.5, and 3.6, the results show that the vitamin contents were decreased by both the sun and oven drying at $100^{\circ} \mathrm{C}$ except for the content of Vit- E in P. santolinoides and $P$. mildbreadii that increased respectively. However sun drying achieved a greater decrease in the content of the vitamins than oven drying at $100^{\circ} \mathrm{C}$.

\section{DISCUSSION}

In table 3.1, potassium levels ranged from $4.50 \pm 0.07 \mathrm{mg} / 100 \mathrm{~g}$ in I. batatas to $9.00 \pm 0.27 \mathrm{mg} / 100 \mathrm{~g}$ in
P.santolinoides and $Z$. anthoxyloides respectively. When sun, and oven dried at $100^{\circ} \mathrm{C}$ (tables 3.2 and 3.3) the value increased with greater increase when oven dried. Daily requirement of potassium is about $1 \mathrm{mg}$ (Robson et al, 1978), and therefore these vegetables are capable of contributing to meeting the need of potassium. It functions as a very important co-factor in many enzyme reactions e.g. glycogen and protein synthesis (Robson et at, 1978). Deficiency does not occur under normal condition except in such situations like starvation, and extensive tissue damage.

Magnesium levels ranged from $1.72 \pm 0.18 \mathrm{mg} / 100 \mathrm{~g}$ in Z.anthoxytoides to $1.31 \pm 0.28 \mathrm{mg} / 100 \mathrm{~g}$ in P.mildbrerdii (table 3.1). When sun and oven dried at $100^{\circ} \mathrm{C}$ (table 3.2 and 3.3), the levels decreased with greater reduction when oven dried. Magnesium activates enzymes particularly those involved in carbohydrate metabolism, regulates nerve impulse transmission, and muscle contraction. Deficiency occurs mainly in alcoholics and in renal disease.

Zinc and manganese occurred in low levels in all the samples. This probably reflects the low status of these elements in the farmland where these vegetables were grown or possible unfavorable complexation reaction with some antinutrient factor eg phytic acid (Nwachukwu, 2002). Iron levels ranged from $6.870 .23 \mathrm{mg} / 100 \mathrm{~g}$ in p. mildbreadii to $5.51 \pm 0.02 \mathrm{mg} / 100 \mathrm{~g}$ in P. santolinoides. Sun and oven drying at $100^{\circ} \mathrm{C}$ decrease the levels (table 3.2 and 3.3). The result shows that the vegetables are good sources of iron particularly when used fresh. Iron apart from acting as co-factor in a number of enzyme-catalyzed reactions e.g. cytochrome oxidase, transports and stores oxygen in haemoglobin and myoglobin (Geoffrey et al, 1995). Phosphorus, calcium and sodium levels were the highest in all the samples studied, ranging from $6.41 \pm 0.13 \mathrm{mg} / 100 \mathrm{~g}$ in $\mathrm{P}$. mildbreadii to $5.58 \pm 0.11 \mathrm{mg} / 100 \mathrm{~g}$ in I. batatas; $14.27 \mathrm{t} 0.41 \mathrm{mg} / 100 \mathrm{~g}$ in I. batatas to $6.85 \pm 0.31 \mathrm{mg} / 100 \mathrm{~g}$ in Z. zanthoxyloides and from $83.79 \mathrm{t} 1.41 \mathrm{mg} / 100 \mathrm{~g}$ in $\mathrm{I}$. batatas to $21.86 \pm 0.06 \mathrm{mg} / 100 \mathrm{~g}$ in $\mathrm{P}$. santolinoides respectively. When sun and oven dried at $100^{\circ} \mathrm{C}$, the levels of these elements increased in all the samples. As the ash component of the samples, heating and drying will tend to increase the levels. This result shows that the vegetables are rich sources of these elements whether fresh or dried. Phosphorus plays a role in bone formation, ATP and nucleic acid synthesis. Calcium is involved in bone formation, blood clotting and stimulation of muscle contraction. Sodium functions as extracellular ion, control of acid-base balance and in active transport (Pender et al, 1997). Calcium deficiency causes rickets and Osteomalacia, while sodium and potassium deficiencies do not occur in human because of the wide distribution in common foodstuff. However, excess loss of sodium can occur during intense sweating, diarrhea, vomiting or adrenal cortical insufficiency (Taylor, 1978).

In table 3.4, the result shows that the vegetables studied are rich in Vit. $A, B_{1}, C$ and folic acid, ranging from $1520.01 \pm 2.00$ i.u. in I. batatas to $671.30 \mathrm{t} 1.70$ i.u in C.Pentandra; $4.57 \pm 0.86 \mathrm{mg} / 100 \mathrm{~g}$ in P.antolinoides to 
$3.57 \pm 0.87 \mathrm{mg} / 100 \mathrm{~g}$ in C. pentandra, and $3.24 \pm 0.03 \mathrm{mg} / 100 \mathrm{~g}$ in $P$. santolinoides to $1.56 \pm 0.98 \mathrm{mg} / 100 \mathrm{~g}$ in C.pentandra respectively. When sun and oven dried at $100^{\circ} \mathrm{C}$ (table 3.5 and 3.6), the values of these vitamins decreased in all the samples. The result also shows that $C$. pentandra had the least values of all the vitamins determined. Also, sun drying produced greater reduction effects on the level of the vitamins compared to oven drying at $100^{\circ} \mathrm{C}$. According to Artery and Dennis (1991). extent of vitamin destruction is dependent on the caution exercised during the preparation of the foodstuff for drying, the condition of drying selected, the care in the execution and the condition of storage of dried food. The greater destructive effect exerted by sun drying as compared to oven drying could have been due to the stability of the vitamins to oven heat. Secondly, since dried vegetables are more concentrated, hence higher levels of the vitamins as compared with sun drying. This implies that the heat generated by the sun may have different effect on the samples than that produced by the oven. Robson et al (1978), suggested that vitamins may be more stable to oven heat than sun light.

Vitamins e.g. A,C, and $E$ are known to be destroyed by drying or heat treatment (Priestly, 1979, Eze, 1995). Vitamin $A$ is important in night vision and deficiency leads to xeropthalamia and kerotomalacia vitamin $B_{1}$ is an important co-enzyme in carbohydrate metabolism and deficiency leads to beriberi. Vitamin $\mathrm{C}$ is a powerful antioxidant and helps to protect other vitamins like, A and $E$. it is also involved in the synthesis of collagen and neurotransmitters e.g. serotonin. Deficiency leads to scurvy as a result of inability of connective tissues to synthesis collagen (Charles and Guy, 1999). Folfc acid is involved in the synthesis of nucleic acid, interconversion of glycine and serine, and methylation of homocysteine to methionine.

\section{SUMMARY AND CONCLUSION}

In summary, the vegetables studied I. batatas, (Potato leaf), P. santolinoides (Uturukpa leaf), Z. zanthoxyloides (Nka leaf), P. mildbreadii (Oha leaf), and C. pentandra (Akpuota leaf), have been found to be rich sources of micronutrients. For the minerals, drying conditions used tend to increase their levels, while vitamin contents were reduced. For the vitamins, sun drying has a greater destructive effect than oven heating.

Similarly, oven drying has a greater increasing effect on the mineral $(\mathrm{K}, \mathrm{P}, \mathrm{Ca}, \mathrm{Na})$ content than sun drying. In drying water content is lost, therefore water soluble nutrients e.g. some vitamins will tend to decease, while mineral which are ash content of the sample tend to increase, Ugwuoke, (2001) reported that sun dried vegetables have higher percentage of moisture content than oven dried ones. It is therefore possible that the higher increases in the mineral content is due to greater reduction in moisture content by over drying. Oven drying therefore appears to be a better drying condition for storage of vegetables.

Table 3.1: The Mineral Composition of the Fresh Samples.

Mineral composition (mg/100g)

\begin{tabular}{|l|l|l|l|l|l|l|l|l|}
\hline Sample & $\mathbf{K}$ & $\mathbf{M g}$ & $\mathbf{Z n}$ & $\mathbf{F e}$ & $\mathbf{P}$ & $\mathbf{M n}(\boldsymbol{\mu g})$ & $\mathbf{C a}$ & $\mathbf{N a}$ \\
\hline I.batatas & $4.50 \pm 0.07$ & $1.44 \pm 0.01$ & $0.50 \pm 0.01$ & $6.25 \pm 0.01$ & $5.83 \pm 0.11$ & $0.65 \pm 0.01$ & $14.27 \pm 0.01$ & $83.79 \pm 1.41$ \\
\hline P.santolinoides & $6.75 \pm 0.21$ & $1.38 \pm 0.03$ & $0.47 \pm 0.03$ & $5.51 \pm 0.02$ & $6.47 \pm 0.10$ & $0.72 \pm 0.07$ & $8.42 \pm 0.42$ & $21.86 \pm 0.06$ \\
\hline Z.zanthoxyloides & $9.00 \pm 0.27$ & $1.72 \pm 0.18$ & $0.93 \pm 0.10$ & $6.74 \pm 0.03$ & $6.35 \pm 0.42$ & $0.41 \pm 0.08$ & $6.35 \pm 0.31$ & $43.70 \pm 0.10$ \\
\hline P.mildbreadii & $9.00 \pm 0.27$ & $1.31 \pm 0.28$ & $0.57 \pm 0.28$ & $6.87 \pm 0.18$ & $6.41 \pm 0.13$ & $0.60 \pm 0.02$ & $11.88 \pm 0.17$ & $36.43 \pm 0.42$ \\
\hline C.pentandra & $6.75 \pm 0.11$ & $1.41 \pm 0.13$ & $0.79 \pm 0.06$ & $6.74 \pm 0.04$ & $6.28 \pm 0.03$ & $0.59 \pm 0.06$ & $11.84 \pm 0.06$ & $29.15 \pm 0.34$ \\
\hline
\end{tabular}

All values are mean \pm SD 3 determination

Table 3.2: The mineral composition of sun dried samples

\begin{tabular}{|l|l|l|l|l|l|l|l|l|}
\hline & & & & & & & & \\
Sample & $\mathbf{K}$ & $\mathbf{M g}$ & $\mathrm{Zn}$ & $\mathbf{F e}$ & $\mathbf{P}$ & $\mathbf{M n}(\boldsymbol{\mu g})$ & $\mathbf{C a}$ & $\mathrm{Na}$ \\
\hline I.batatas & $29.25 \pm 0.06$ & $0.97 \pm 0.03$ & $0.35 \pm 0.08$ & $5.51 \pm 0.03$ & $7.18 \pm 0.25$ & $14.31 \pm 0.00$ & $83.79 \pm 0.00$ & $83.79 \pm 0.06$ \\
\hline P.santolinoides & $25.88 \pm 0.17$ & $0.97 \pm 0.06$ & $0.21 \pm 0.07$ & $4.27 \pm 0.03$ & $7.63 \pm 0.04$ & $10.50 \pm 0.83$ & $10.50 \pm 0.83$ & $51.00 \pm 0.08$ \\
\hline Z.zanthoxyloides & $24.75 \pm 1.13$ & $1.25 \pm 0.11$ & $0.53 \pm 0.03$ & $5.51 \pm 0.07$ & $7.76 \pm 0.00$ & $0.36 \pm 0.01$ & $9.77 \pm 1.10$ & $58.29 \pm 0.05$ \\
\hline P.mildbreadii & $22.50 \pm 0.14$ & $1.19 \pm 0.01$ & $0.43 \pm 0.04$ & $5.44 \pm 0.08$ & $6.60 \pm 0.03$ & $0.50 \pm 0.10$ & $10.23 \pm 0.95$ & $69.22 \pm 1.40$ \\
\hline C.pentandra & $29.25 \pm 0.00$ & $1.13 \pm 0.06$ & $0.71 \pm 0.10$ & $5.94 \pm 0.28$ & $6.99 \pm 0.04$ & $0.49 \pm 0.03$ & $13.96 \pm 0.50$ & $36.43 \pm 0.60$ \\
\hline
\end{tabular}

All values are mean \pm SD 3 determination 
Table 3.3: Mineral composition of oven dried samples at $100^{\circ} \mathrm{C}$

\begin{tabular}{|l|l|l|l|l|l|l|l|l|}
\hline Sample & $\mathbf{K}$ & $\mathbf{M g}$ & $\mathbf{Z n}$ & $\mathbf{F e}$ & $\mathbf{P}$ & $\mathbf{M n}(\boldsymbol{\mu g})$ & $\mathbf{C a}$ & $\mathbf{N a}$ \\
\hline I.batatas & $42.75 \pm 0.20$ & $0.97 \pm 0.03$ & $0.35 \pm 0.08$ & $5.51 \pm 0.03$ & $7.18 \pm 0.25$ & $0.34 \pm 0.05$ & $14.31 \pm 0.05$ & $102.00 \pm 0.64$ \\
\hline P.santolinoides & $27.00 \pm 0.30$ & $0.97 \pm 0.06$ & $0.21 \pm 0.07$ & $4.27 \pm 0.03$ & $7.63 \pm 0.04$ & $0.41 \pm 0.02$ & $10.50 \pm 0.83$ & $80.15 \pm 0.10$ \\
\hline Z.zanthoxyloides & $27.00 \pm 0.50$ & $1.25 \pm 0.11$ & $0.53 \pm 0.03$ & $5.51 \pm 0.07$ & $7.76 \pm 0.00$ & $0.36 \pm 0.01$ & $9.77 \pm 1.10$ & $91.08 \pm 0.75$ \\
\hline P.mildbreadii & $31.50 \pm 0.00$ & $1.19 \pm 0.01$ & $0.43 \pm 0.04$ & $5.44 \pm 0.08$ & $6.60 \pm 0.03$ & $0.50 \pm 0.10$ & $10.23 \pm 0.95$ & $83.79 \pm 0.43$ \\
\hline C.pentandra & $28.13 \pm 1.01$ & $0.76 \pm 0.17$ & $0.43 \pm 0.05$ & $2.16 \pm 0.06$ & $7.88 \pm 0.89$ & $0.11 \pm 0.01$ & $18.88 \pm 0.05$ & $54.65 \pm 0.56$ \\
\hline
\end{tabular}

Table 3.1: The Vitamin composition of the Fresh Samples

Vitamin Composition

\begin{tabular}{|l|l|l|l|l|l|l|}
\hline Sample & $\mathbf{A}(\mathbf{I . U})$ & $\mathbf{B}_{\mathbf{1}}(\mathbf{m g} / \mathbf{1 0 0} \mathbf{g})$ & $\mathbf{B}_{\mathbf{2}}(\mathbf{m g} / \mathbf{1 0 0 g})$ & $\mathbf{C}(\mathbf{m g} / \mathbf{1 0 0 g})$ & $\mathbf{E}(\mathbf{m g} / \mathbf{1 0 0 g})$ & $\mathbf{F . A ( m g / 1 0 0 g})$ \\
\hline I. batatas & $1520.01 \pm .2 .10$ & $3.07 \pm 0.65$ & $1.59 \pm 0.09$ & $5.36 \pm 0.10$ & $1.95 \pm 0.10$ & $3.17 \pm 0.00$ \\
\hline P. santolinoides & $686.70 \pm 1.50$ & $4.57 \pm 0.86$ & $0.59 \pm 0.01$ & $7.11 \pm 0.20$ & $0.59 \pm .02$ & $3.24 \pm 0.03$ \\
\hline Z.zanthoxylodies & $764.00 \pm 0.96$ & $4.32 \pm 0.76$ & $0.36 \pm 0.01$ & $9.04 \pm 0.72$ & $0.47 \pm 0.01$ & $3.16 \pm 0.02$ \\
\hline P.mildbreadii & $980.10 \pm 1.16$ & $3.38 \pm 0.87$ & $0.48 \pm 0.00$ & $7.43 \pm 0.50$ & $7.71 \pm 0.05$ & $2.49 \pm 0.99$ \\
\hline C. pentandra & $671.30 \pm 1.70$ & $2.63 \pm 0.02$ & $060 \pm 0.02$ & $3.57 \pm 0.87$ & $0.58 \pm 0.06$ & $1.56 \pm 0.98$ \\
\hline
\end{tabular}

All values are mean \pm SD 3 determination

Tables $3.5 \quad$ The vitamin composition of sample after sun drying

\begin{tabular}{|l|l|l|l|l|l|l|}
\hline Sample & $\mathbf{A}(\mathbf{I . U})$ & $\mathbf{B}_{\mathbf{1}}(\mathbf{m g} / \mathbf{1 0 0 g})$ & $\mathbf{B}_{\mathbf{2}}(\mathbf{m g} / \mathbf{1 0 0 g})$ & $\mathbf{C}(\mathbf{m g} / \mathbf{1 0 0 g})$ & $\mathbf{E}(\mathbf{m g} / \mathbf{1 0 0 g})$ & $\mathbf{F} . \mathbf{m g} / \mathbf{1 0 0 g})$ \\
\hline I. batatas & $439.70 \pm 0.50$ & $171 \pm 0.10$ & $1.3 \pm 0.21$ & $1.68 \pm 0.24$ & $0.49 \pm 007$ & $1.53 \pm 0.19$ \\
\hline P. santolinoides & $208.30 \pm 0.40$ & $3.24 \pm 0.95$ & $0.14 \pm 0.01$ & $1.71 \pm 0.01$ & $1.23 \pm 0.23$ & $1.84 \pm 0.23$ \\
\hline Z.zanthoxylodies & $54.00 \pm 0.95$ & $2.96 \pm 0.09$ & $0.8 \pm 0.00$ & $5.24 \pm 0.10$ & $0.12 \pm 0.25$ & $0.18 \pm 001$ \\
\hline P.mildbreadii & $594.00 \pm 0.60$ & $1.15 \pm 0.07$ & $0.21 \pm 0.01$ & $1.75 \pm 0.01$ & $175 \pm 0.25$ & $0.18 \pm 001$ \\
\hline C. pentandra & $517.00 \pm 0.60$ & $1.07 \pm 0.05$ & $0.11 \pm 0.00$ & $1.61 \pm 0.00$ & $0.06 \pm 0.00$ & $0.73 \pm 0.02$ \\
\hline
\end{tabular}

$$
\text { F.A = Folic Acid }
$$

Table 3.6 The vitamin composition of sample after Oven Drying At $100^{\circ}$

\begin{tabular}{|l|l|l|l|l|l|l|}
\hline Sample & A(I.U) & $\mathbf{B}_{1}(\mathbf{m g} / \mathbf{1 0 0 g})$ & $\mathbf{B}_{\mathbf{2}}(\mathbf{m g} / \mathbf{1 0 0 g})$ & $\mathbf{C}(\mathbf{m g} / \mathbf{1 0 0 g})$ & $\mathbf{E}(\mathbf{m g} / \mathbf{1 0 0 g})$ & F.A(mg/100g) \\
\hline I. batatas & $1497.00 \pm 0.17$ & $3.04 \pm 04$ & $1.59 \pm 0.08$ & $1.96 \pm 0.02$ & $1.94 \pm 0.52$ & $0.71 \pm 0.07$ \\
\hline P. santolinoides & $67.00 \pm 1.04$ & $4.53 \pm 0.94$ & $0.58 \pm 0.03$ & $1.64 \pm 0.23$ & $0.66 \pm 05$ & $0.70 \pm 0.05$ \\
\hline Z.zanthoxylodies & $371.00 \pm 0.19$ & $430 \pm 0.83$ & $0.35 \pm 0.04$ & $4.16 \pm 0.97$ & $0.46 \pm 0.02$ & $0.47 \pm 0.05$ \\
\hline P.mildbreadii & $956.70 \pm 0.23$ & $3.28 \pm 0.56$ & $0.47 \pm 0.01$ & $1.37 \pm 0.09$ & $0.70 \pm 0.04$ & ND \\
\hline C. pentandra & $956.70 \pm 26$ & $2.55 \pm 0.15$ & $0.59 \pm 0.20$ & $0.64 \pm 0.01$ & $0.59 \pm 0.11$ & $0.19 \pm 0.02$ \\
\hline
\end{tabular}

All values are mean \pm SD 3 determination $\mathrm{ND}=$ Not detected 


\section{REFERENCES}

Arthey, D. and Dennis C,, 1991. Vegetable Processing. Chapman and hall London.

Charles, A. and Guy, L ., 1999. Food Biochemistry. Aspen publication Maryland U.S.A.

David, P., 1978. Chemical Analysis of Food. Church Living Stone. U.S.A.

Eze J. I., 1995. Comparative Studies on Open Air Sun Drying and Solar Drying of some Leafy Vegetables. NJRE, 2 (2): 20-25.

Geoffrey, L. Z, William, W. P. and Dennis, E. V., 1995. Principle of Biochemistry. WMC Brown Comm.. Oxford

Maud, J. K., 1999. Processing and Preservation of Tropical and Subtropical Food; Macmillan, Hong Kong.

Nwachukwu, N., 2002. Studies on the Nutritional and Antinutntional factors from some selected Nigerian Indigenous Spices, Ph.D Thesis; FUTO.

Odo, F. O. and Ishiwu C. N., 1999. Experimental Procedure for Food and Water Analysis. Computer Edge, Enugu.
Oguntona, T., 1998. Green Leafy Vegetables in Nutritional Quality of Plant Foods. (Osagie. U.A and Eka, O.U. Eds) Postharvest Res. Unit Biochemistry, University of Benin.

Okoli. E. C. Nmorka, 0. 0 and Unaegbu. N. B., 1998. Blanching and Storage for some Nigerian Vegetables. Int. J. Fd. Sc. Tech. 23639-641.

Pearson, D., 1978. The Chemical Analysis of Foods. Longman Group Ltd. London.

Pender, F, Van N. K. and Van N. M, 1997. Nutrition and Dietetics as Practical Guide to Normal and therapeutic nutrition. Cayon Pres Ltd, London.

Priestly, R. J., 1979. Effects of Heating on Food Stuffs. App . Sci. Publ. London.

Robson, J. R. K, Francis, A. L, Arita, M. S. and Bahram, T., 1978. Malnutrition, its Causation and Control Gordon and Breach, New York.

Taylor, T.G., 1978. Perspective in Mineral Nutrition. Proc. Nutr. Soc. 34, 35-41.

Ugwoke, C.C., 2001. Chemical Composition of some Leafy Vegetables used as Food Condiments in Nsukka L.G.A. B.Sc, (Project) U.N.N. 